\title{
REMARKABLE CHANGES IN THE SKULL OF AN AMERICAN BADGER (TAXIDEA TAXUS) DUE TO ADVANCED AGE
}

By Dr. R. W. Shufeldt

\section{[Plate 10]}

While recently engaged in comparing the skulls of certain American mustelines and one from Hungary, namely the skull of a specimen of the European badger (Meles meles), with the view of preparing a brief monograph on the subject, I met with the skull of an American badger among the material kindly loaned me by the United States National Museum for this purpose, which seems to be worthy of special description. This skull is numbered 22253, but carries no data on its attached label beyond the statement that it is the skull of a specimen of Meles taxus. If Meles taxus stands for the European badger, this diagnosis is an error, as the skull is from an aged specimen of an American badger -Taxidea taxus. Each and all of its characters have been compared by me with the corresponding ones as presented in the skull of a very large American badger and the aforesaid skull of the European species (Meles meles), No. 171964, Hungary Acad., C. Jones.

The skull from the American one belonged to a very large specimen collected by W. S. Wood on the Republican Fork of the Platte River, on the 28th of September, 1856 (227), and carries the number of the National Museum of $2572\left(\sigma^{7}\right)$. Beyond the loss of the left hamular process of the post palatine, it appears to be perfect in all particulars. As in a number of our mustelines, when they grow old, the mandible is nearly permanently locked to the cranium at either of its articulations, - that is, by the anterior and posterior articular eminences of the glenoid fossæ of the temporals at the posterior termination of either zygomatic arch. This locking, which is complete in many instances, occurs in various species, or rather in the skulls of old animals of our American forms, and has long been known; but whether it is ever seen in the skulls of badgers of the Old World I am not informed, though I am inclined to believe that it does not. It is not seen in the skull of Meles meles at hand, which came from an animal long adult.

Turning to the skull here to be compared and described, it is found to have an extreme length of $12 \mathrm{cms}$., and an extreme width (interzygomatic) of $8 \mathrm{cms}$., as compared with the skull No. 2572, which presents corresponding measurements of $12.3 \mathrm{cms}$. and $8.3 \mathrm{cms}$. The European badger (No. 171964) possesses a long and narrow skull 
having an extreme length of $12.3 \mathrm{cms}$. and a width of only $6.3 \mathrm{cms}$. In general form, measurements, and facies, it has more the appearance of the skull of a very large Marten (Martes americana) than that of our badger, and it will not be further considered in the present connection, as its full description will appear later on, when the characters of all the skulls of the mustelines at hand will be described.

Passing now to the skull of the aged badger, it is first to be noted that the external surfaces of the cranium and mandible have a roughish feel and fine, porous appearance in some places, more particularly on the bones of the face and over the parietal region.

Viewed upon its superior aspect, the cerebral casket of the cranium is more or less globular in form, the two superficies being separated by a very prominent, mesial sagittal crest of bone, the superior rim of which is more or less thickened. The crest averages a centimeter in height for its posterior moiety, tapering away as we pass forward, to run out as raised rims limiting the temporal fossæ anteriorly (fig. 1).

Turning to the badger skull No. 2572 (fig. 2), this crest is seen to have an average height of hardly more than a millimeter; while its anterior branches, limiting the temporal fossa upon either side, are practically flush with the general surface of the cranium. In this badger, instead of being globular in form, the vault of the cranium has an outline of an isosceles triangle, its broad base being the raised rim of the occipital crest. The middle point of this crest is triangularly indented, while its lateral terminations are curved, causing their surfaces to face forwards and upwards. The extreme width at this point measures $8.2 \mathrm{cms}$. All this is entirely different in the cranium of our aged badger, wherein the occipital crest, though prominent, is low down on the cranium, circular in outline, and terminating on either side just below the osseous auricular opening. The occipital area below this crest is much limited in extent; concave supermesially, and terminating in a sharp, thin, concave edge as the superior margin of the very large foramen magnum.

In the American badger the occipital region is very extensive, being perpendicular to the longitudinal axis of the cranium, and reniform in outline - the large foramen magnum being in the center, below, and the superior elliptical curve being formed by the limiting occipital crest. These parts in the crania of the two animals present such wide differences in the matter of characters that, were there naught else to go by, the mammalogist that placed the individuals exemplifying them in different families would probably be sustained by his confrères. 

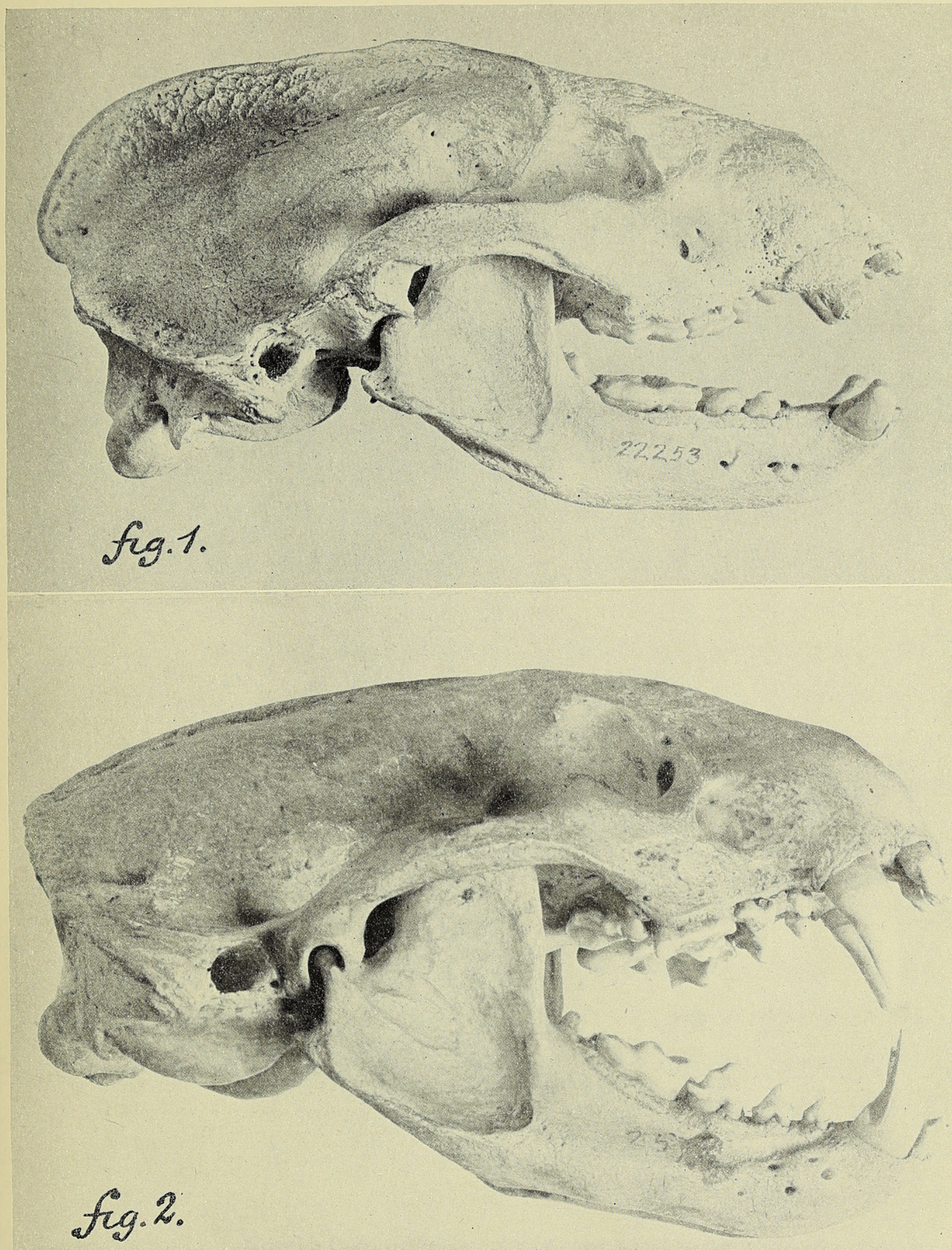

SKulls OF BADGERS

FIg. 1. Skull of a very old American Badger (Taxidea taxus) seen on right lateral view; mandible articulated; natural size. Frg. 2. Same view, natural size, of the skull of an adult specimen of the American Badger (Taxidea taxus), No. 2572, Coll. U. S. Nat. Museum. 
Viewed upon its facial aspect, the cranium of this old badger presents the usual musteline characters of its genus. The infraorbital foramen is large and of different outline in the two skulls here being compared, as in the aged badger its outer arc is curved, to be angulated in the larger skull.

Upon anterior view, the narial aperture is always seen to be large and oval in outline in a badger, the long axis being mesial and vertical. The ethmoidal bones are extremely complicated and spongy, extending far forwards in this aged badger, and being far back in the skull here shown in figure 2. Vomer is to some extent incomplete.

One of the best evidences of great age in the skull here being described is the condition of its dental armature, most of the incisor teeth being lost, others broken, and the remainder all worn-worn down to an extent never before observed by me in any ferine mammal. As these teeth stand, however, it is very evident that, in the matter of the formula, they agreed originally with that of Taxidea taxus.

Beyond the extraordinary wearing away of the teeth, the mandible of our subject essentially agrees in all of its characters with what we find in the lower jaw of our common badger-the position and number of foramina having no weight. It is not permanently locked at its articulations in the glenoid fossæ. Beyond the evidences of great age, the characters seen at the basis cranii are typically taxidean, an apparent shrinkage of the auditory bulloe alone constituting any marked difference.

Washington, D. C. 


\section{$2 \mathrm{BHL}$ Biodiversity Heritage Library}

Shufeldt, Robert W. 1922. "Remarkable Changes in the Skull of an American Badger (Taxidea taxus) Due to Advanced Age." Journal of mammalogy 3 , 173-175. https://doi.org/10.2307/1373664.

View This Item Online: https://www.biodiversitylibrary.org/item/220041

DOI: https://doi.org/10.2307/1373664

Permalink: https://www.biodiversitylibrary.org/partpdf/90560

\section{Holding Institution}

Smithsonian Libraries

\section{Sponsored by}

Biodiversity Heritage Library

\section{Copyright \& Reuse}

Copyright Status: Not in copyright. The BHL knows of no copyright restrictions on this item.

This document was created from content at the Biodiversity Heritage Library, the world's largest open access digital library for biodiversity literature and archives. Visit BHL at https://www.biodiversitylibrary.org. 